\title{
A new species of the genus Tetragonopterus Cuvier, 1816 (Ostariophysi: Characiformes: Characidae) from the rio Tocantins drainage, Brazil
}

\author{
Leonardo B. S. Araujo and Paulo H. F. Lucinda
}

A new species of the genus Tetragonopterus is described from specimens of the upper and middle portions of the rio Tocantins drainage. The new species can be distinguished from all congeners by the possession of a very uniquely shaped maxilla.

Uma espécie nova do gênero Tetragonopterus é descrita a partir de espécimes das porções superior e média da bacia do rio Tocantins. A espécie nova pode ser distinguida de todas as congêneres pela maxila de formato único.

Key words: Ichthyofauna, Neotropical, Systematics, Taxonomy.

\section{Introduction}

The genus Tetragonopterus Cuvier comprises characids distributed throughout the drainages of the río Orinoco, rio Amazonas, rio Tocantins-Araguaia, rio São Francisco, rio Paraná-Paraguay, the coastal drainages of the Guianas, and the Amapá State of Brazil, and the coastal drainages of northeastern and eastern Brazil (Melo et al., 2011; Reis, 2003). The genus currently comprises seven species considered valid (Silva et al., 2013). Recent ichthyofaunal surveys in the upper and middle portions of the rio Tocantins drainage yielded samples of a new species of Tetragonopterus that we formally describe herein.

\section{Material and Methods}

Examined specimens belong to the following fish collections: Departamento de Zoologia e Botânica, Universidade Estadual Paulista “Júlio de Mesquita Filho”, câmpus de São José do Rio Preto, São José do Rio Preto (DZSJRP); Laboratório de Biologia e Genética de Peixes, Universidade Estadual Paulista “Júlio de Mesquita Filho", câmpus de Botucatu, Botucatu (LBP); Museu de Ciências e Tecnologia da Pontifícia Universidade Católica do Rio Grande do Sul, Porto Alegre (MCP); Museu de Zoologia da Universidade de São Paulo, São Paulo (MZUSP);
Coleção Ictiológica do Núcleo de Pesquisas em Limnologia, Ictiologia e Aquicultura da Universidade Estadual de Maringá, Maringá (NUP); Universidade Federal do Rio Grande do Sul, Departamento de Zoologia, Porto Alegre (UFRGS); and Laboratório de Ictiologia Sistemática, Universidade Federal do Tocantins, Porto Nacional (UNT). Measurements follow Fink \& Weitzman (1974), except for the exclusion of length of paired and unpaired fins, and distance from dorsal-fin origin to the orbit. All measurements of subunits of the head were expressed as percents of head length (HL). Measurements were made on the left side of specimens whenever possible. Counts follow Fink \& Weitzman (1974) except for the inclusion of number of scale rows ventral to the lateral line to the pelvic-fin insertion. In the description section the numbers in parentheses after each count represent the frequency of that count and asterisks indicate counts of the holotype. Specimens referred to as c\&s were cleared and stained according to the procedures described in Taylor \& Van Dyke (1985). Counts of teeth and tooth cusps, gill rakers, and vertebral counts were obtained from c\&s specimens. The counts of vertebrae included the first four vertebrae modified into the Weberian apparatus (sensu Fink \& Weitzman, 1974) and the compound caudal centrum (PU1 + U1; sensu Lundberg \& Baskin, 1969) was counted as one vertebral element. 


\section{Results}

\section{Tetragonopterus akamai, new species}

Figs. 1-2

Holotype. MCP 48033, 56.5 mm SL, female, Brazil, Tocantins, Peixe, rio Tocantins close to confluence with rio Santa Tereza, 11\%47'27'S 48 37'2'W, 7 Oct 2002, staff of the Núcleo de Estudos Ambientais, Universidade Federal do Tocantins (Neamb-UFT).

Paratypes. All collected by Neamb-UFT staff (ordered from North to South). Brazil. Tocantins. UNT 8210, 1, $61.2 \mathrm{~mm}$ SL, Palmas, praia do Prata, 10¹3'29'S 48²2'15'W, 28 Nov 2002. UNT 2807 , 1, $60.6 \mathrm{~mm}$ SL, Porto Nacional, rio Tocantins, praia Porto Real, approximately $10^{\circ} 43^{\prime} \mathrm{S} 48^{\circ} 24^{\prime} \mathrm{W}, 6$ Jun 1996. UNT 5160, 1, $47.0 \mathrm{~mm}$ SL, same locality as UNT 2807, 6 Jul 1996. UNT 2797, 1 c\&s, 54.3 mm SL, Brejinho de Nazaré, lagoa Pedra do Santo, approximately $11^{\circ} 01^{\prime} \mathrm{S} 48^{\circ} 34^{\prime} \mathrm{W}, 24$ Nov 1996. UNT 10268, 11, 8.2-44.7 mm SL, same locality as UNT 2797, 12 Mar 1997. MCP 48034, 3, 52.9-57.9 mm SL, and UNT 5176, 7 (1 c\&s), 51.1-59.2 mm SL, Brejinho de Nazaré, lagoa Capivara, approximately $11^{\circ} 01^{\prime} \mathrm{S} 48^{\circ} 35^{\prime} \mathrm{W}, 14 \mathrm{Feb}$ 1996. UNT 2788, 1 c\&s, 54.4 mm SL, Brejinho de Nazaré, lagoa Capivara, approximately $11^{\circ} 01^{\prime} \mathrm{S} 48^{\circ} 35^{\prime} \mathrm{W}, 14$ Feb 1995. UNT 3544, 10, 33.2-42.1 mm SL, Ipueiras, rio Tocantins, approximately $11^{\circ} 19^{\prime} \mathrm{S} 48^{\circ} 28^{\prime} \mathrm{W}, 20$ Apr 2001. UNT 10263, 1, $48.9 \mathrm{~mm}$ SL, same locality as UNT 3544, 8 Aug 2002. UNT 5175, 5, 35.1-37.1 mm SL, same locality as UNT 3544, 28 Nov 2001. UNT 8626, 1, 39.8 mm SL, same locality as UNT 3544, 28 Nov 2002. UNT 3548, 1, 54.0 mm SL, Peixe, lagoa Dionísio, fazenda Água Branca, 1144'49”S 4838'16"W, 18 Mar 2001. UNT 2787, 1, 47.1 mm SL, same locality as holotype, 3 Jun 2002. UNT 5174, 1, 55.6 mm SL, same locality as holotype, 9 Sep 2002. UNT 10264, 1, $46.6 \mathrm{~mm} \mathrm{SL}$, collected with the holotype. UNT 2792, 1, $47.6 \mathrm{~mm}$ SL, MCP 48036, 4, 44.9$45.8 \mathrm{~mm}$ SL, and UNT 3521, 4, 38.1-42.1 mm SL, Peixe, rio Santa

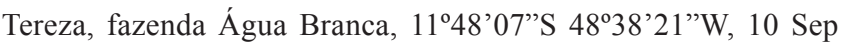
2002. UNT 2800, 2, 49.7-50.4 mm SL, Peixe, fazenda Água Branca, lagoa Água Branca, 11\%49'20'S 48³8'40”W, 13 Oct 2000. UNT 5162, 1 c\&s, 47.1 mm SL, same locality as UNT 2800, 3 Jun 2002. UNT 10265, 1, $52.9 \mathrm{~mm}$ SL, same locality as UNT 2800, 22 May 2001. UNT 10267, 1, 37.0 mm SL, Peixe, rio Tocantins, UHE Peixe Angical, approximately $12^{\circ} 15^{\prime}$ 'S $48^{\circ} 23^{\prime} \mathrm{W}, 24$ May 2005. UNT 464, 1 c\&s, 46.5 mm SL, Paranã, rio Palmeiras drainage, 28 Oct 2002. UNT 2785, 1, 52.8 mm SL, Paranã, rio Tocantins, fazenda Traçadal, approximately $12^{\circ} 29^{\prime} \mathrm{S} 48^{\circ} 12^{\prime} \mathrm{W}$. UNT 2793,1 c\&s, $53.9 \mathrm{~mm}$ SL, Paranã, lagoa Traçadal, fazenda Traçadal, approximately $12^{\circ} 29^{\prime}$ S $48^{\circ} 12^{\prime}$ W. UNT 10266, 1, 55.6 mm SL, Paranã, rio Paranã, fazenda Traçadal, approximately 12³0’S 48¹2’W, 24 Mar 1998.

Diagnosis. Tetragonopterus akamai is distinguished from all its congeners by a very uniquely shaped maxilla in the manner described below and depicted in Fig. 2. The anterodorsal portion of the maxilla that is articulated with the premaxilla is bent over and in close contact with the dorsal surface of the premaxilla (vs. anterodorsal portion of the maxilla articulated with the premaxilla not bent over and not in contact with the dorsal surface of the premaxilla; see Fig. 2 and Silva \&

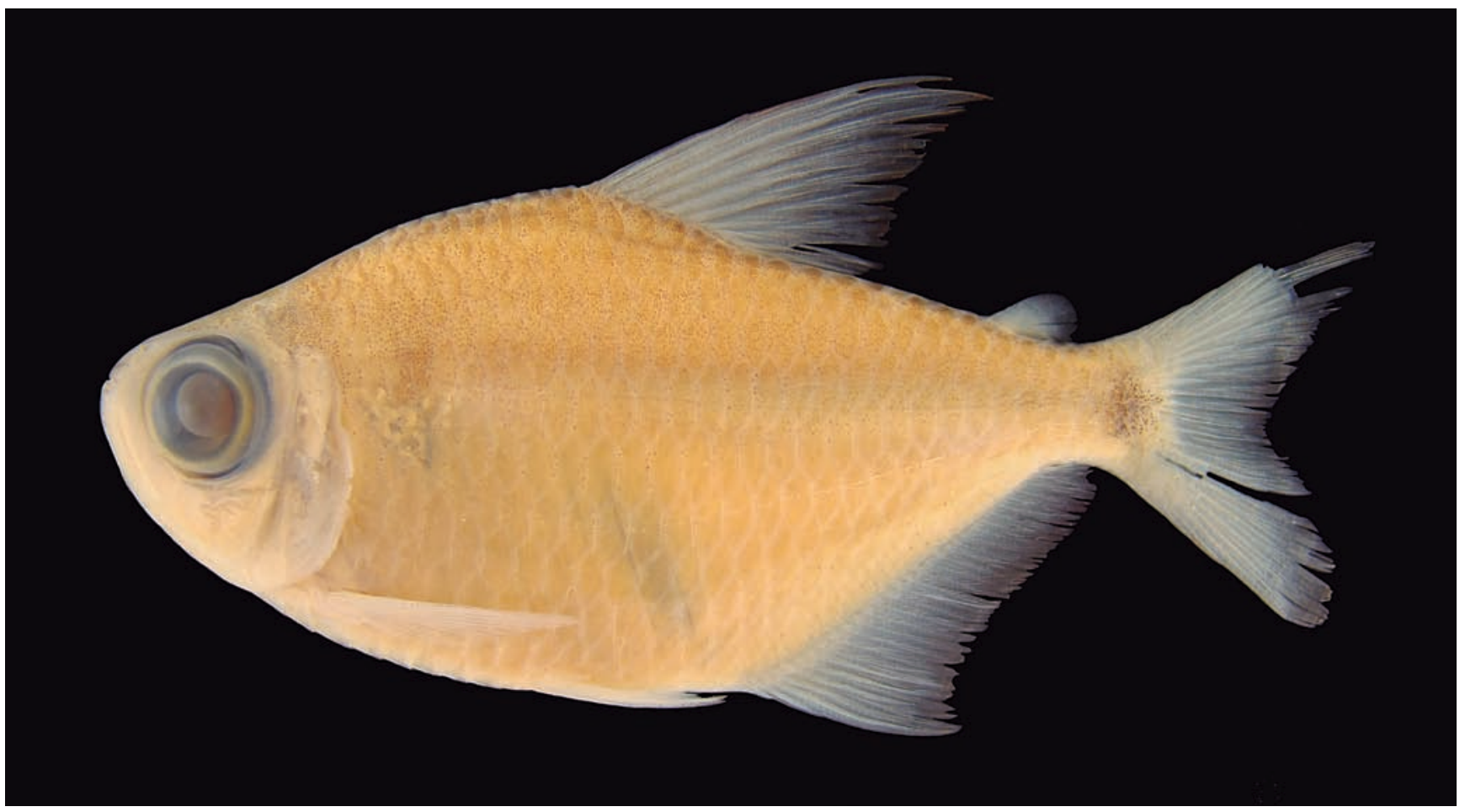

Fig. 1. Tetragonopterus akamai, MCP 48033, holotype, female, $56.5 \mathrm{~mm}$ SL, Peixe, rio Tocantins close to confluence with rio Santa Tereza. 
Benine, 2011: fig. 2). The anterodorsal portion of the maxilla articulated with the premaxilla is very short, $c a$. 5.5-5.9\% of length of the free portion of the maxilla (vs. much longer, $c a$. 16.6-20\% in the remaining species; see Fig. 2 and Silva \& Benine, 2011: fig. 2). The anterodorsal border of the proximal portion of the maxilla articulated with the premaxilla is concave and angled approximately 90 degrees relative to the free portion of the maxilla (vs. continuous and not angled or angled approximately 45 degrees relative to the free portion of the maxilla in the remaining species; see Silva \& Benine, 2011: fig. 2). The tip of the anterodorsal portion of the maxilla that is articulated with the premaxilla does not reach the vertical through the anterior margin of the antepenultimate teeth of the inner premaxillary series (vs. surpassing such vertical in the remaining species). Tetragonopterus akamai further differs from $T$. argenteus Cuvier; $T$. chalceus Spix \& Agassiz; T. denticulatus Silva, Melo, Oliveira \& Benine; T. araguaiensis Silva, Melo, Oliveira \& Benine, T. rarus Zarske, Géry \& Isbrücker; and T. carvalhoi Melo, Benine, Mariguela \& Oliveira in the position of the mouth (superior vs. terminal, respectively). Tetragonopterus akamai can also be distinguished from T. anostomus Silva \& Benine by the longer snout (20.0-27.6\% vs. 9.5-14.3\% HL, respectively) and by the relative size of the teeth on the inner premaxillary series, which are much larger than those of the outer series (vs. teeth of the inner premaxillary series as large as or smaller than those of the outer series in T. anostomus). Tetragonopterus akamai can be further differentiated from $T$. anostomus by the number of gill rakers on the first branchial arch (9-10/14-16 vs. 11/18, respectively). Tetragonopterus akamai can be distinguished from $T$. rarus in the absence of dark longitudinal stripes along the flanks (vs. presence of such stripes in T. rarus). Tetragonopterus akamai can be further differentiated from T. carvalhoi in the shape of the patch of dark pigmentation on the caudal peduncle (a round blotch restricted to the posterior half of the caudal peduncle $v$ s. a lozenge-shaped blotch stretching out the whole extension of the caudal peduncle, respectively) (compare Fig. 1 with Melo et al., 2011: Fig 2a), and in the higher number of gill rakers on the lower limb of the first branchial arch (14-16 vs. 13, respectively). Tetragonopterus akamai differs from T. argenteus in the number of predorsal scales (7-10 vs. 1317, respectively). Tetragonopterus akamai can be further distinguished from T. araguaiensis by: (1) the number of large teeth on the dentary (five or six vs. four, respectively); (2) the possession of overall relatively smaller dentary teeth with pointed cusps (vs. overall robust dentary teeth with roundish cusps, respectively); (3) the longer snout (20.0$27.6 \%$ vs. $14.3-18.1 \%$ HL, respectively); and (4) the number of gill rakers on the lower limb of the first gill arch (14-16 vs. 19-20, respectively). Tetragonopterus akamai can be further distinguished from $T$. denticulatus by (1) the distance

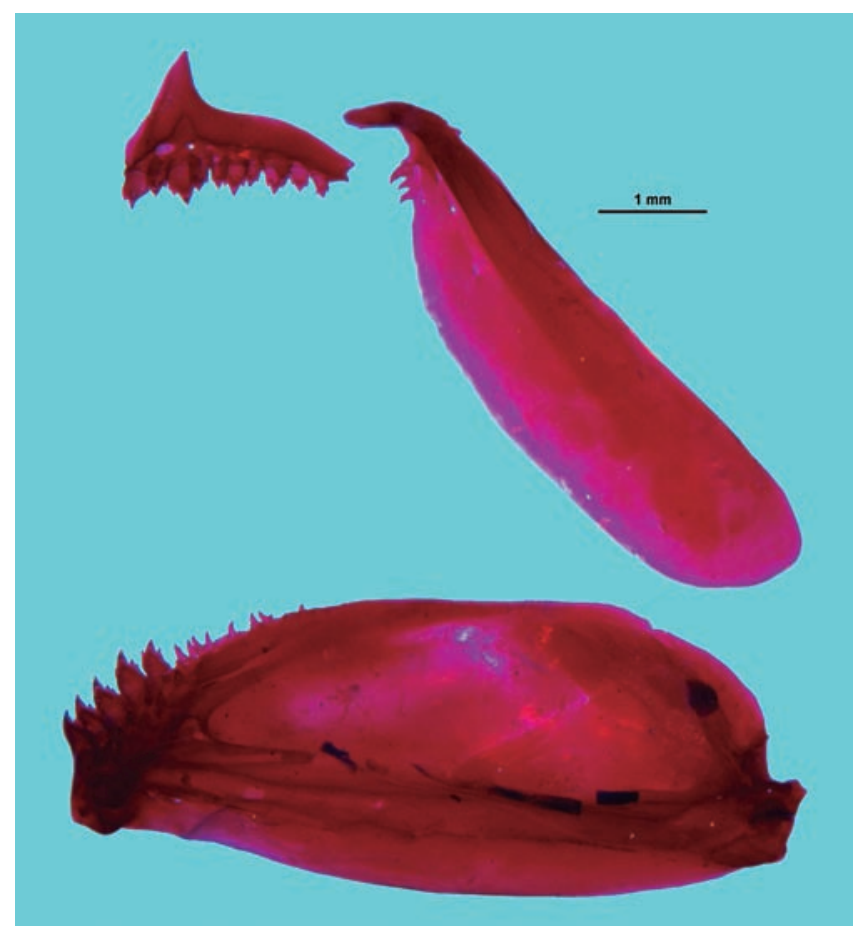

Fig. 2. Tetragonopterus akamai, UNT 464, paratype, 46.5 $\mathrm{mm}$ SL. Left side of premaxilla, maxilla, and lower jaw. Scale bar $=1 \mathrm{~mm}$.

between the first and second humeral blotches (distant 1-1.5 scales from each other in horizontal direction vs. distant 3 scales from each other, respectively); and (2) by the longer snout (20.0-27.6\% vs. 10.9-18.4\% HL, respectively).

Description. Morphometric data in Table 1. Body moderately deep and laterally compressed. Greatest depth at dorsal-fin origin. Predorsal profile slightly straight from snout tip to extremity of supraoccipital bone and concave from that point to dorsal-fin origin. Postdorsal profile straight from base of last dorsal-fin ray to origin of adipose fin and convex from latter point to end of caudal peduncle. Ventral profile concave from snout to origin of pelvic fin. Ventral area between pelvic-fin insertion and anal-fin origin pronouncedly flattened. Sides of flattened area keeled. Margin of anal fin oblique along base of anal-fin rays. Ventral profile concave from base of last anal-fin ray to end of caudal peduncle.

Mouth superior. Two rows of premaxillary teeth. Teeth of internal row approximately twice as wide as teeth of external row. Teeth of external row of premaxilla approximately of same size. Five (3) or 6 (3) tri- or tetracuspid teeth in external row of premaxilla with pointed cusps of approximately similar size. First, or first and second anteriormost teeth as well as posteriormost teeth of external premaxillary row with three cusps and remaining teeth with four cusps. Teeth of internal row of premaxilla of approximately similar size. Five (5) or 6 (1) 
tri- or pentacuspid teeth in internal row of premaxilla with pointed cusps. Central cusps larger than lateral ones. First, or first and second anteriormost teeth as well as penultimate and last posteriormost teeth of internal premaxillary row with three cusps. Remaining teeth with five cusps. Anterodorsal portion of maxilla that is articulated with premaxilla very short, $c a$. 5.5-5.9\% of maxillary free portion length. Anterodorsal border of proximal portion of maxilla articulated with premaxilla concave (Fig. 2). Anterodorsal portion of maxilla articulated with premaxilla approximately angled 90 degrees relative to free portion of maxilla (Fig. 2). Tip of anterodorsal portion of maxilla articulated with premaxilla not reaching vertical passing through anterior margin of antepenultimate teeth of inner premaxillary series. Three (4) or 4 (2) teeth of approximately similar size on proximal portion of maxilla. First, second, and third maxillary teeth unicuspid. Fourth tooth, when present, with central cusp and two or three lateral minute cusps (Fig. 2). Five (3) or 6 (3) anteriormost dentary teeth larger, followed by 9 (1) or 12 (5) smaller teeth. Anterior large teeth of dentary with 3 , 4 , or 5 cusps. Posterior small teeth of dentary with one or two cusps.

Table 1. Morphometric data of Tetragonopterus akamai. Values are given as percents of standard length or head length. Range includes the holotype ( $\mathrm{n}=$ number of specimens; $\mathrm{H}=$ holotype; Min. = minimum; Max. = maximun).

\begin{tabular}{|c|c|c|c|c|c|}
\hline & Holotype & $\mathrm{n}$ & Paratypes & Mean & $\overline{\mathrm{SD}}$ \\
\hline Standard Length (mm) & 37.7 & 30 & $26.6-37.7$ & 33.2 & - \\
\hline \multicolumn{6}{|c|}{ Percentages of Standard Length } \\
\hline Depth at dorsal-fin origin & 34.9 & 30 & $28.6-36.6$ & 33.1 & 2.1 \\
\hline Snout to dorsal-fin origin & 49.3 & 30 & $38.4-54.3$ & 50.5 & 2.6 \\
\hline Snout to pectoral-fin origin & 25.9 & 30 & $25.1-28.5$ & 26.9 & 0.9 \\
\hline Snout to pelvic-fin origin & 45.8 & 30 & $44.1-49.0$ & 46.4 & 1.3 \\
\hline Snout to anal-fin origin & 59.7 & 30 & $58.6-63.7$ & 61.3 & 1.4 \\
\hline Caudal-peduncle depth & 11.0 & 30 & $9.4-11.6$ & 10.6 & 0.6 \\
\hline Caudal-peduncle length & 10.8 & 30 & $8.0-12.8$ & 10.9 & 1.1 \\
\hline Pectoral-fin length & 22.9 & 30 & $20.8-24.7$ & 22.2 & 1.1 \\
\hline \multicolumn{6}{|l|}{ Pelvic-fin length } \\
\hline Males & 22.5 & 11 & $18.8-23.8$ & 21.7 & 1.6 \\
\hline Females/immatures & - & 16 & 15.8 & 18.0 & 1.0 \\
\hline Pelvic-fin origin to anal-fin origin & 16.5 & 30 & $14.3-18.5$ & 16.3 & 1.0 \\
\hline \multicolumn{6}{|l|}{ Dorsal-fin length } \\
\hline Males & 44.9 & 11 & $31.6-44.9$ & 35.6 & 3.7 \\
\hline Female & 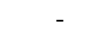 & 16 & 32.9 & 30.3 & 1.2 \\
\hline Dorsal-fin base length & 14.7 & 30 & $12.5-16.1$ & 14.4 & 0.9 \\
\hline \multicolumn{6}{|l|}{ Anal-fin length } \\
\hline Males & 27.3 & 11 & 27.3 & 25.3 & 1.9 \\
\hline Females/im & 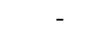 & 16 & 24.4 & 22.3 & 1.1 \\
\hline Anal-fir & 33.4 & 30 & 33.5 & 31.3 & 1.4 \\
\hline rigin & 37.2 & 30 & 48.9 & 37.7 & 2.4 \\
\hline origin to caudal-f & 52.8 & 30 & $48.3-54.5$ & 51.6 & 1.5 \\
\hline Hеа & 27.2 & 30 & 23.5 & 26.5 & 1.4 \\
\hline Head length & 23.7 & 30 & $23.7-26.7$ & 25.0 & 0.8 \\
\hline \multicolumn{6}{|c|}{ Percentages of Head Length } \\
\hline eye diameter & 42.8 & 30 & $23.0-50.1$ & 44.1 & 5.7 \\
\hline Snout length & 26.1 & 30 & $21.7-33.5$ & 25.5 & 2.0 \\
\hline Interorbital width & 35.3 & 30 & $31.4-36.8$ & 33.6 & 1.4 \\
\hline Upper jaw length & 44.6 & 30 & $43.1-50.1$ & 46.3 & 1.7 \\
\hline
\end{tabular}

Scales cycloid. Lateral line complete and distinctly ventrally curved anteriorly. Perforated scales on lateral line 29 (1), 30 (16), 31* (7), 32 (16), 33 (5), or 35 (1). Scale rows between dorsal-fin origin and lateral line $6^{*}(23)$ or 7 (23). Scale rows between lateral line and pelvic-fin origin 3 (2), $4 *$ (16), 5 (26), or 6 (2). Scale rows between lateral line and anal-fin origin $3 *(28)$ or 4 (18). Longitudinal scale rows around caudal peduncle 10 (1), 11 (15), 12* (22), or 13 (8). Predorsal scales 7 (2), 8 (24), 9* (17), or 10 (3) arranged in regular series.

Dorsal-fin rays ii,8 (7) or ii,9* (39). Pectoral-fin rays i,11 (12), i,12* (21), or i,13 (9). Pelvic-fin rays i,6 (1) or i,7* (45). Anal-fin rays iii,27* (3), iii,28 (3), iii,29 (4), iii,30 (3), iii,31 (1), iii,32 (1), iii,33 (2), iii,34 (1), iv,26 (1), iv,27 (3), iv,28 (8), iv,29 (13), or iv,30 (3). Some specimens exhibiting sheath of small scales arranged in two rows along anal-fin base. Branched caudal-fin rays 18* (14), 19 (26), or 20 (6). Caudal fin scaled on some specimens, with first fifth basal portion of upper and lower lobe covered with small scales.

Precaudal vertebrae 11 (1), 12 (2), or 13 (3). Caudal vertebrae 18 (2), 19 (1), or 20 (3). Total vertebrae 30 (1), 31 (1), or 33 (3). Supraneurals 3 (4) or 4 (2). Dorsal procurrent rays 7 (2) or 10 (4). Ventral procurrent rays 5 (1), 6 (3) or 7 (2).

Color in alcohol. Background color yellow. Two pale brown humeral spots, vertically elongate and separated by one to one and half scales from each other. Each humeral spot covering three to four scales in vertical direction and one and half scale in horizontal direction. First humeral spot more prominent than second and distant one to two scales length from posteriormost point of operculum. Silver band extending along midline of flanks from region just posterior to distal border of opercle to base of caudal-fin rays. Rounded and well-defined light brown blotch on caudal peduncle. Fins hyaline.

Sexual dimorphism. Mature males can be recognized by the presence of bony hooks on the pelvic- and anal-fin rays. Hooks are present along extension of last unbranched anal-fin ray and along extension of first to seventh branched anal-fin rays and along extension of first five or first six branched pelvic-fin rays. The smallest mature male examined is $46.5 \mathrm{~mm}$ SL.

Distribution. Tetragonopterus akamai is known from the upper and middle portions of the rio Tocantins drainage (Fig. 3).

Etymology. The specific name akamai (noun masculine genitive singular) is a patronym for Alberto Akama, in recognition of his contributions to Neotropical ichthyology and in recognition of his many collecting efforts on several South American drainages. 


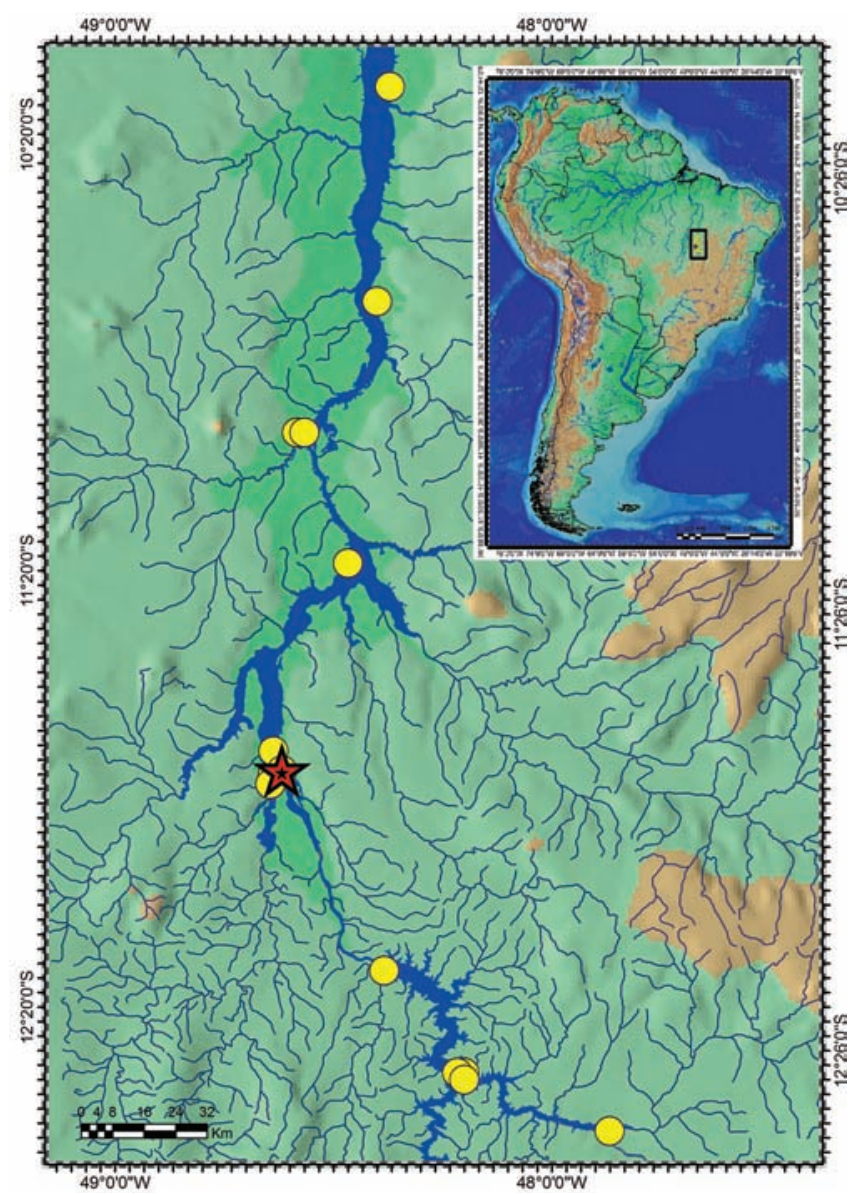

Fig. 3. Map of rio Tocantins drainage, showing the known distribution of Tetragonopterus akamai. Some symbols represent more than one lot or locality. Red star indicates the type locality. Inset depicts the area of South America displayed in the map.

\section{Discussion}

Eigenmann (1917: 54) diagnosed Tetragonopterus in the following manner, which we below reproduce verbatim omitting some fragments and stressing the most important traits: "Small fishes, $[\ldots]$ much compressed and very deep, the depth at least half the length; [...] snout very short, the maxillary nearly vertical; $[\ldots]$ premaxillary teeth in two rows [...] several large, graduated, several pointed teeth in the front of the lower jaw, abruptly minute teeth on the sides; maxillary with or without teeth on its upper anterior edge [...] the anal long, 32-37; scales entire, large on the middle of the sides, becoming smaller in all directions, notably toward front of anal [...] lateral line complete, much decurved, several scales between its origin and that of the regular series below it [...] preventral area flat, bounded by sharp angles, a median series of scales on the breast; [...] This genus, most nearly allied to Moenkhausia, is readily distinguished from it by the greatly decurved lateral line which is not parallel with the row of scales below it in front”.
Given that a cladistic diagnosis (i.e., hypothesis of monophyly) of Tetragonopterus is not available to date, the traditional non-cladistic diagnosis of Eigenmann reproduced above is still broadly used. Therefore, in the absence of a cladistic diagnosis we opted to describe Tetragonopterus akamai as a species of Tetragonopterus species because it better conforms to the current non-cladistic Eigenmann's (1917: 54) diagnosis of the genus. Moreover, Tetragonopterus akamai exhibits three supraneurals and a branched laterosensory canal in the sixth infraorbital, both conditions proposed as diagnostic for Tetragonopterus by Melo et al. (2011: 53).

Mirande (2010: 503) hypothesized eight character states as autapormorphic for Tetragonopterus argenteus. These character states were herein evaluated for T. akamai. 1) The laterosensory canal in the sixth infraorbital of T. akamai is tripartite, exhibiting an anterior dorsal portion running towards the neurocranium. 2) Tetragonopterus akamai exhibits of a lateral line tube lying onto the membrane between the middle caudal fin-rays. 3) The lamellar portion of the maxilla of $T$. akamai possesses a bifurcated canal with one elongate branch parallel to the dorsal margin of the maxilla plus a short branch (one fourth to one third of the length of the elongate branch) directed and parallel to the anterior margin of maxilla along one third of its length. 4) The ethmopalatine cartilage of $T$. akamai is large. 5) The base of the second pectoral fin-ray in T. akamai is swelled and extends laterally and beyond the base of first pectoral fin-ray. 6) The anterior border of scales of T. akamai is conspicuously and regularly undulated, and their radii converge to the center. 7) Finally, Tetragonopterus akamai exhibits two conspicuous and vertical humeral spots. 8) All the above-mentioned character states displayed by $T$. akamai are congruent with and can be coded in the same manner as those of $T$. argenteus.

We also evaluated the conditions of those character states (Mirande's (2010) characters 76, 93, 98, 171, 231, 318, 322, and 342) for the seven remaining species of Tetragonopterus. The character states exhibited by the specimens examined endorsed the conclusion that the following seven out of the eight autapomorphies listed by Mirande (2010) for T. argenteus are indeed apomorphies shared with all its congeners and therefore are herein interpreted as putatively synapomorphic for the genus Tetragonopterus, namely: (1) laterosensory canal of sixth infraorbital branched (character state 76-1), (2) caudal-fin canal of lateral line almost reaching posterior margin of caudal fin (character state 93-1); (3) tubules for passage of blood vessels on lamellar portion of maxilla with anterior branch running parallel to anterior margin of maxilla and reaching one third of its length (character state 98-1); (4) conspicuous ethmopalatine cartilage (character state 171-1); (5) base of second pectoral ray large and partially overlapping base of first pectoral ray from medial view (character state 2310); (6) anterior margin of scales with conspicuous undulations 
(character state 318-1); and (7) radii of scales converging at focus (character state 322-1). However, a conspicuous and vertically elongate second humeral spot (character state 342-1) is present in T. akamai, T. araguaiensis, T. argenteus, T. carvalhoi, T. chalceus, and T. denticulatus, whereas $T$. anostomus and $T$. rarus display the plesiomorphic state (absent or inconspicuous). Therefore, character state 342-1 is not herein proposed as a putative synapomorphy of the genus Tetragonopterus, but for a less inclusive clade.

Moreover, Melo et al. (2011: 53) postulated that the presence of three supraneural bones could be a diagnostic feature of Tetragonopterus. The new species T. akamai and all seven congeners have three supraneurals.

Testing the hypothesis of monophyly is not the aim of the present paper. Nonetheless we suggest a provisional diagnosis of Tetragonopterus relying on the combination of character states by Eigenmann (1917), on the presence of three supraneurals, and on the seven supposed synapomophies above-mentioned until the hypothesis of monophyly of the genus Tetragonopterus is tested.

Four additional nominal species of Tetragonopterus have been described based on specimens from the rios TocantinsAraguaia drainage, namely $T$. anostomus, $T$. araguaiensis, $T$. denticulatus, and $T$. sawa Castelnau ( $=T$. argenteus). Besides $T$. argenteus and $T$. chalceus have also been reported from the rio Tocantins drainage. It is noteworthy that $T$. anostomus, T. araguaiensis, and T. denticulatus are known from the rio Araguaia and have not been recorded to date from the remaining portions of the rio Tocantins drainage. Nonetheless, T. anostomus, T. araguaiensis, T. argenteus, T. chalceus, and T. denticulatus clearly differ from T. akamai as detailed in the "Diagnosis" section.

A fourth species-name is available for the rio Tocantins drainage. Tetragonopterus sawa was described by Castelnau (1855: 65; pl. 33, fig. 1) from specimens of rio Crixás, an affluent to rio Araguaia. Hitherto the nomenclatural status of $T$. sawa is uncertain and it was treated as Species Inquirenda by Lima et al. (2003: 161). However, we examined a photograph of the holotype of T. sawa (MNHN A-9819) and we concluded that the specimen exhibits 14 pre-dorsal scales (vs. 7-10 in $T$. akamai), which allowed us to infer that $T$. sawa and T. akamai are not conspecific. Tetragonopterus sawa is most likely a junior synonym of T. argenteus as previously recognized by Eigenmann (1917: 56) and suggested by Silva \& Benine (2011: 54).

Comparative material. Tetragonopterus araguaiensis. Brazil. Goiás. LBP 4154, 1, 62.3 mm SL, paratype, Aragarças, rio Araguaia. LBP 7756, 1 c\&s, 33.1 mm SL, paratype, Cocalinho, rio Araguaia. MCP 41394, 1, 57.2 mm SL, Piranhas, rio Piranhas, near mouth of rio São Domingos, affluent of rio Araguaia. NUP 14678, 3, 53.1$55.9 \mathrm{~mm}$ SL, São Miguel do Araguaia, lago Luís Alves, affluent to rio Araguaia. Mato Grosso. DZSJRP 3897, 4, 47.0-57.7 mm SL,
Santa Teresinha, rio Araguaia. Tetragonopterus argenteus. Brazil. Goiás. UNT 724, 1, 95.4 mm SL, Minaçu, rio Maranhão. UNT 725, 1, 85.3 mm SL, Niquelândia, rio Maranhão. UNT 726, 1, 99.4 mm SL, Niquelândia, rio Maranhão. Maranhão. UNT 2803, 1, 52.1 mm SL, Estreito, rio Tocantins close to confluence with rio Itaueiras. Tocantins. UNT 435, 1, 99.1 mm SL, Paranã, rio Palmeiras. UNT 2758, 3, 66.1-80.7 mm SL; UNT 2759, 2, 67.1 and $75.3 \mathrm{~mm} \mathrm{SL}$; UNT 2765, 1, 64.9 mm SL; UNT 2780, 1, 76.4 mm SL; UNT 2791, 1, 71.7 mm SL; UNT 3506, 1 c\&s, 76.8 mm SL; and UNT 3507, 2, 55.7 and 78.7 mm SL; Porto Nacional, rio Tocantins. UNT 2760, 1, 108.2 mm SL, Paranã, rio Maranhão, fazenda Traçadal. UNT 2761, 1, 82.4 mm SL; UNT 2764, 1, 73.7 mm SL; and UNT 2770, 1 c\&s, $62.3 \mathrm{~mm}$ SL; Pedro Afonso, rio Tocantins close to confluence with rio Sono. UNT 2768, 2, 63.4 and 84.8 mm SL; UNT 2777, 1, 80.5 mm SL; and UNT 2781, 1, 67.4 mm SL; Brejinho de Nazaré, lagoa Capivara. UNT 2769, 1, 81.8 mm SL, Santa Rosa, rio Manoel Alves. UNT 2801, 3, 27.0-31.2 mm SL, Brejinho de Nazaré, lagoa Pedra do Santo. UNT 3504, 1, 89.9 mm SL, Lajeado, rio Tocantins. UNT 4227, 1, $46.7 \mathrm{~mm} \mathrm{SL}$; and UNT 5167, 1, 35.8 mm SL; Ipueiras, rio Tocantins close to confluence with rio Manoel Alves. UNT 7173, 3, 62.2-68.7 mm SL, Peixe, rio Tocantins, upstream UHE Peixe Angical. UNT 7693, 2, 81.1 and 82.2 mm SL; and UNT 8163, 1, 90.7 mm SL; Paranã, rio Paranã, close to confluence with rio Lages. UNT 8055, 1, 80.5 mm SL, São Salvador, rio Maranhão, close to Distrito Retiro. UNT 10220, 1, 52.6 mm SL, border of municípios de Sucupira and Peixe, rio Santa Tereza. Paraguay. MCP 15619, 6, rio Paraguai, Cáceres. Tetragonopterus anostomus. Brazil. Goiás. LBP 7687, 2, 37.9 and 39.6 mm SL, paratype, Cocalinho, marginal lake near rio Araguaia. MCP 44638, 1, 57.8 mm SL, São Miguel do Araguaia, rio Verde. MCP 44661, 6, 34.4-40.9 mm SL, Britânia, stream of rio Araguaia drainage. MZUSP 108957, 1, 45.4 mm SL, holotype, Nova Crixás, rio Preto. MZUSP 89295, 5, 50.9-42.7 mm SL, paratopotypes. UFRGS 11627, 4, 30.4-41.1 mm SL, Barra do Garças, ribeirão Corrente near road BR-158 towards Nova Xavantina. Tetragonopterus carvalhoi: Brazil. Amapá. LBP 5376, 2, 42.1 and $44.2 \mathrm{~mm}$ SL, paratypes, collected with the holotype. MZUSP 101755, 2, 39.5 and $4.2 \mathrm{~mm} \mathrm{SL}$, rio Jari, upstream and downstream cachoeira Santo Antônio. MZUSP 102268, 1, 36.5 mm SL, holotype, Laranjal do Jari, igarapé Iratapuru, rio Jari. MZUSP 103376, 4, 44.8-64.5 $\mathrm{mm}$ SL, Laranjal do Jari, igarapé três bocas, affluent to rio Pacanari downstream cachoeira Santo Antônio. MZUSP 106813, 2, 59.2 and 63.4 mm SL, paratopotypes. MZUSP 101708, 1, 60.7 mm SL, Monte Dourado, rio Jari. Tetragonopterus chalceus. Brazil. Tocantins. UNT 2762, 1, 70.8 mm SL; UNT 2766, 3, 2 c\&s, 51.8-55.6 mm SL; and UNT 2794, 1, 59.2 mm SL, Paranã, rio Paranã, fazenda Traçadal. UNT 2771, 2, 1 c\&s, 57.1 and 74.0 mm SL; UNT 2778, 1, 75.0 mm SL; and UNT 10277, 2, 51.3 and 62.6 mm SL; Paranã, rio Maranhão, fazenda Traçadal. UNT 2772, 2, 71.5-74.3 mm SL; and UNT 2783, 2, 1 c\&s, 54.8-65.0 mm SL; Brejinho de Nazaré, lagoa Capivara. UNT 2775, 1, 90.4 mm SL; UNT 2790, 1, 54.0 mm SL; and UNT 3523, 4, 50.6-66.4 mm SL, Peixe, rio Santa Tereza. UNT 2779, 3, 55.4-57.5 mm SL; UNT 6476, 1, 37.1 mm SL; UNT 
10274, 1, 56.6 mm SL; and UNT 10275, 2, 53.9-59.1 mm SL; Porto Nacional, rio Tocantins. UNT 2784, 1, 54.6 mm SL, Porto Nacional, rio Mangues. UNT 2795, 1, 53.7 mm SL, Ipueiras, rio Formiga close to confluence with rio Tocantins. UNT 2799, 1, $57.1 \mathrm{~mm} \mathrm{SL}$, Brejinho de Nazaré, rio Crixás. UNT 3505, 1, 79.3 mm SL, Peixe, lagoa Dionísio, fazenda Água Branca. UNT 3508, 3, 62.5-79.3 mm SL, Tupirama, rio Tocantins close to confluence with rio Tranqueira. UNT 3509, 3, 52.9-55.9 mm SL, Peixe, lagoa Água Branca, fazenda Água Branca. UNT 3510, 2, 55.1-71.7 mm SL, Peixe, rio Tocantins close to confluence with rio Santa Tereza. UNT 3511, 1, $66.2 \mathrm{~mm}$ SL, Lajeado, rio Tocantins, fish ladder. UNT 3540, 2, 49.2 and 51.3 $\mathrm{mm}$ SL, Porto Nacional, rio Tocantins near to the confluence with rio Feio. UNT 3543, 6, 50.1-56.4 mm SL, Paranã, rio Paranã close to lagoa Verde. UNT 3546, 10, 36.5-44.3 mm SL, Peixe, rio Tocantins close to confluence with rio Almas. UNT 5161, 2, 50.7-55.4 mm SL, Paranã, rio Paranã, lagoa Traçadal. UNT 8052, 1, 1, 71.2 mm SL, Paranã, córrego das Pedras. UNT 10276, 1, 30.3 mm SL, Peixe, rio Tocantins close to UHE Peixe Angical. Tetragonopterus denticulatus. Brazil. Goiás. DZSJRP 13587, 5, 46.7-52.1 mm SL, Aragarças, Praia Quarto Crescente, rio Araguaia. LBP 5751, 2, 1 c\&s, 50.4-55.8 mm SL, parátipos, Aragarças, rio Araguaia. Mato Grosso. MZUSP 42782, 4, 29.6-37.8 mm SL, Barra do Garças, rio Araguaia. MZUSP 89182, 4, 41.0-47.6 mm SL, Cocalinho, rio Araguaia. Tetragonopterus rarus. Brazil. Pará. MZUSP 88029, 1, 74.0 mm SL, Alto Pará do Oeste, rio Amazonas, affluent to rio Tírios. Suriname. LIRP 4928, 2 cs, 47.547.9 mm SL, and LIRP 4929, 1, $79.8 \mathrm{~mm}$ SL, tributary to Sisa Creek, Nickerie. MZUSP 99689, 1, 86.2 mm SL, Maroni, Marowjine Rivier.

\section{Acknowledgments}

We are indebted to Carla Pavanelli and Weferson Graça (NUP); Carlos Lucena and Margarete Lucena (MCP); Cláudio Oliveira and Ricardo Benine (LBP); Francisco Langeani (DZSJRP); Luiz Malabarba (UFRGS) and Osvaldo Oyakawa (MZUSP) for the loan of specimens. We owe special thanks to Laurent Nandrin, Patrice Pruvost, and Michel Jégu (MNHN) for the photos and data on the holotype of Tetragonopterus sawa. We wish to thank the anonymous reviewers for critically reviewing the manuscript. Anderson Soares (UNT) photographed the holotype of Tetragonopterus akamai and edited Figs. 1 and 2. We thank Everton Oliveira (UNT) and Thiago Pereira (LIRP) for assistance in various tasks during this study. We owe special thanks to Tiago Krolow (UFT) for obtaining the images of the Fig. 2. PHFL and LBSA are partially supported by grants from Conselho Nacional de Desenvolvimento Científico e Tecnológico (CNPq proc. 308018/2011-7 and 383423/2013-9, respectively).

\section{Literature Cited}

Castelnau, F. L. 1855. Expédition dans les parties centrales de L'Amérique du Sud, de Rio de Janeiro à Lima, et de Lima au Pará; exécutée par ordre du gouvernement français pendant les années 1843 a 1847, sous la direction du Comte Francis de Castelnau. Ouvrage qui a obtenu une médaille hors ligne de la société de géographie. Zoologie. Poissons. Paris, Libraire P. Bertrand.

Eigenmann, C. H. 1917. The American Characidae [Part 1]. Memoirs of Museum of Comparative Zoology at Harvard College, 43: 1-102.

Fink, W. L. \& S. H. Weitzman. 1974. The so-called Cheirodontin fishes of Central America with descriptions of two new species (Pisces: Characidae). Smithsonian Contributions to Zoology, 1: 1-46.

Lima, F. C. T., L. R. Malabarba, P. A. Buckup, J. F. P. Silva, R. P. Vari, A. Harold, R. Benine, O. T. Oyakawa, C. S. Pavanelli, N. A. Menezes, C. A. S. Lucena, M. C. S. L. Malabarba, Z. M. S. Lucena, R. E. Reis, F. Langeani, L. Casatti, V. A. Bertaco, C. Moreira \& P. H. F. Lucinda. 2003. Genera incertae sedis in Characidae. Pp. 106-169. In: Reis, R. E., S. O. Kullander \& C. J. Ferraris Jr. (Eds.). Check List of the Freshwater Fishes of South and Central America. Porto Alegre, Edipucrs.

Lundberg, J. G. \& J. N. Baskin. 1969. The caudal skeleton of the catfishes, order Siluriformes. American Museum Novitates, 2398: 1-49.

Melo, B. F., R. C. Benine, T. C. Mariguela \& C. A. Oliveira. 2011. New species of Tetragonopterus Cuvier, 1816 (Characiformes: Characidae: Tetragonopterinae) from the rio Jari, Amapá, northern Brazil. Neotropical Ichthyology, 9: 49-56.

Mirande, J. M. 2010. Phylogeny of the family Characidae (Teleostei: Characiformes): from characters to taxonomy. Neotropical Ichthyology, 8: 385-568.

Reis, R. E. 2003. Subfamily Tetragonopterinae. Pp. 212. In: Reis, R. E., S. O. Kullander \& C. J. Ferraris Jr. (Eds.). Check List of the Freshwater Fishes of South and Central America. Porto Alegre, Edipucrs.

Silva, G. S. C., B. F. Melo, C. Oliveira \& R. C. Benine. 2013. Morphological and molecular evidence for two new species of Tetragonopterus (Characiformes: Characidae) from central Brazil. Journal of Fish Biology, 82: 1613-1631.

Silva, G. S. C. \& R. C. Benine. 2011. A new species of Tetragonopterus Cuvier, 1816 (Characiformes, Characidae,Tetragonopterinae) from the upper rio Araguaia, Central Brazil. Zootaxa, 2911: 50-56.

Taylor, W. R. \& G. C. Van Dyke. 1985. Revised procedures for staining and clearing small fishes and other vertebrates for bone and cartilage. Cybium, 9: 107-119.

Submitted September 30, 2013

Accepted April 18, 2014 by Luiz R. Malabarba

Published June 30, 2014 